\title{
PERTANGGUNG JAWABAN PIDANA TERHADAP TERDAKWA TINDAK PIDANA PERZINAAN
}

\author{
Istiklal \\ Program Magister Ilmu Hukum,Universitas Ekasakti, Padang, Indonesia \\ Email: istiqlalsh069@gmail.com
}

\begin{abstract}
Criminal Accountability Against Defendants of the Crime of Adultery On 70/PID.Sus/2020/PN-SWL And Decision Number 90/Pid.B/2020/Pnbkt is on Decision Number 70/PID.Sus/2020/PN-SWL where the defendant is guilty of committing a crime "intentionally being the object of containing pornographic content and a man who is married commits adultery (overspel) with a prison term of 8 (eight) months. The judge did not consider the act of intentionally becoming an object containing pornographic content as regulated in the pornography law, but only imposed a criminal offense against adultery with a maximum penalty of 9 months imprisonment. The criminal responsibility for the criminal act of adultery in Decision Number 90/PID.B/2020/PNBKT is "to participate in committing adultery even though it is known that they are still bound by a legal marriage". In this case, the defendant is a person who is not yet bound by marriage so that in the sentencing of the crime, the defendant is not the main perpetrator or "dader". The defendant was deemed guilty because he knew that witness Zulkifli was still bound by a legal marriage with witness Ismarni but still committed adultery with the defendant Zulkifli. Judge's consideration of the Defendant of the Crime of Adultery in Decision Number 70/PID.Sus/2020/PN-SWL And Judgmentally Decision Number 90/Pid.B/2020/Pnbkt is on Decision Number 70/PID.Sus/2020/PN-SWL the fulfillment of the element of adultery and the element of recording the adultery committed. In Decision Number 90/PID.B/2020/PNBKT the juridical considerations of Article 284 of the Criminal Code paragraph (1) to 1 are fulfilled as a person who participates in committing adultery with someone who he knows is still bound by marriage.
\end{abstract}

Keywords: Adultery, Criminal Liability, Defendant

\section{ABSTRAK}

Pertanggung Jawaban Pidana Terhadap Terdakwa Tindak Pidana Perzinaan. Pada 70/PID.Sus/2020/PN-SWL Dan Putusan Nomor 90/Pid.B/2020/Pnbkt adalah pada Putusan Nomor 70/PID.Sus/2020/PN-SWL dimana terdakwa bersalah melakukan tindak pidana "dengan sengaja menjadi objek yang mengandung muatan pornografi dan seorang pria yang telah menikah, melakukan zina (overspel) dengan pidana penjara selama 8 (delapan) bulan. Hakim tidak mempertimbangan perbuatan dengan sengaja menjadi objek yang mengandung muatan pornografi yang ditur pada undang undang pornografi namun hanya menjatuhkan pidana terhadap perbuatan perzinaan dengan pidana mendekati maksimal yaitu pidana penjara selama 9 bulan. Pertanggungjawaban pidana tindak pidana perzinaan pada Putusan Nomor 90/PID.B/2020/PNBKT adalah "turut melakukan Perzinahan padahal diketahui masih terikat perkawinan yang sah". Dalam hal ini terdakwa adalah seorang yang masih belum terikat perkawinan sehingga dalam penjatuhan pidananya, terdakwa adalah sebagai turut serta 
melakukan bukan pelaku utama atau "Dader". Terdakwa dianggap bersalah karena mengetahui bahwa saksi Zulkifli masih terikat perkawinan yang sah dengan saksi Ismarni namun tetap melakukan perbuatan zinah dengan terdakwa zulkifli. Pertimbangan Hakim Terhadap Terdakwa Tindak Pidana Perzinaan Pada Putusan Nomor 70/PID.Sus/2020/PN-SWL Dan Putusan Nomor 90/Pid.B/2020/Pnbkt adalah pada Putusan Nomor 70/PID.Sus/2020/PN-SWL secara yuridis terpenuhinya unsur perzinaan dan unsur merekam perbuatan zina yang dilakukan. Pada Putusan Nomor 90/PID.B/2020/PNBKT pertimbangan yuridis Pasal 284 KUHP ayat (1) ke 1 terpenuhi sebagai orang yang turut serta melakukan perbuatan zina dengan seseorang yang dia ketahui orang tersebut masih terikat perkawinan.

Kata Kunci: Perzinahan, Pertanggungjawaban pidana, Terdakwa

\section{PENDAHULUAN}

Hukum adalah sebuah entitas yang sangat kompleks, meliputi kenyataan yang menjemuk mempunyai banyak aspek dimensi dan fasset, bila diibaratkan sebagai benda maka hukum sebagai permata yang tiap irisan dan sudutnya akan memberikan kesan berbeda bagi setiap orang yang melihat atau memandangnya. Negara Republik Indonesia merupakan Negara berdasarkan hukum yang berarti kedudukan hukum amatlah tinggi bagi negara Indonesia dimana segala aspek kehidupan tentunya harus diatur dalam suatu sistem hukum. Semenjak seseorang lahir ke Dunia hingga meninggalkan dunia, hukum telah mengikat dirinya baik sebagai subjek maupun objek hukum. Namun, walaupun kehidupan kita telah dibentengi oleh hukum, tapi tetap saja terjadi perubahan struktur tata nilai sosial budaya di dalam masyarakat dewasa ini. Perubahan struktur tersebut meliputi segala aspek kehidupan. Perubahan tersebut antara lain dipengaruhi oleh kemajuan ilmu pengetahuan dan teknologi. ${ }^{1}$

Adapun ketentuan ketentuan hukum perzinahan yang telah ada sejak masa sebelum Islam menjadi agama penduduk atau rakyat di Indonesia. Hal itu dapat dilihat dari undang undang Majapahit yang telah memuat larangan perzinahan dan hukuman terhadap para pelakunya. Perbuatan zina atau mukah, merupakan tindak pidana yang diatur pada Pasal 284 KUHP adalah merupakan hubungan seksual atau persetubuhan di luar perkawinan yang dilakukan oleh seorang laki laki dan seorang perempuan yang kedua duanya atau salah satunya masih terkait dalam perkawinan dengan orang lain. Yang dimaksud dengan persetubuhan, menurut R. Soesilo, adalah peraduan antara kemaluan laki laki dan perempuan yang bisa dijalankan untuk mendapatkan anak. Anggota kelamin laki laki harus masuk ke dalam anggota kelamin perempuan, sehingga mengeluarkan air mani, sesuai dengan Arrest Hooge Raad.

Larangan hubungan seksual yang dapat dikategorikan sebagai tindak pidana zina atau jarimah zina, selain zina itu dilakukan oleh orang yang masih terikat perkawinan, baik salah sorang pelaku zina atau kedua duanya, menurut KUHP, juga termasuk orang yang melakukan persetubuhan dengan seorang perempuan yang sedang dalam keadaan pingsan atau tidak berdaya, sebagaimana ditentukan dalam Pasal 286 KUHP yang berbunyi :

"Barangsiapa bersetubuh dengan seorang wanita yang bukan isterinya, padahal diketahuinya bahwa wanita itu dalam keadaan pingsan atau tidak berdaya, diancam dengan pidana penjara paling lama Sembilan tahun “.

\footnotetext{
${ }^{1}$ Hanif Nurcholis, Teori dan Praktik Pemerintahan \& Otonomi Daerah, Grasindo, Jakarta, 2007, hlm.
} 31 
Berdasarkan uraian diatas bahwa perbuatan persetubuhan di luar perkawinan yang dapat dimasukkan sebagai perbuatan pidana adalah : ${ }^{2}$

a) Persetubuhan di luar perkawinan yang dilakukan oleh seorang laki laki dan seorang perempuan yang kedua duanya atau salah seorang pelakunya sedang dalam ikatan perkawinan yang sah dengan orang lain, atau

b) Persetubuhan di luar perkawinan yang dilakukan oleh seorang laki laki terhadap perempuan yang dalam keadaan pingsan, atau

c) Persetubuhan di luar perkawinan yang dilakukan oleh seorang laki laki terhadap perempuan yang dalam keadaan tidak berdaya, atau

d) Persetubuhan di luar perkawinan yang dilakukan oleh seorang laki laki terhadap perempuan yang diketahuinya atau sepatutnya harus diduganya belum berumur 15 (lima belas) tahun.

e) Persetubuhan di luar perkawinan yang dilakukan oleh seorang laki laki terhadap perempuan yang diketahuinya atau sepatutnya harus diduganya belum masanya untuk dikawini.

Jenis delik zina yang ditentukan Pasal 287 ayat (2) KUHP adalah delik aduan absolute (absolute klacht delict). Jika anak yang disetubuhi di luar perkawinan itu belum berumur 12 (dua belas) tahun, atau perempuan tersebut mengalami luka berat atau kematian, sebagaimana ditentukan dalam Pasal 291 dan Pasal 294 KUHP, maka jenis delik tersebut, bukan lagi merupakan delik aduan, tetapi merupakan delik umum. Sebagaimana telah diketahui, bahwa perbuatan zina dalam KUHP termasuk kejahatan (misdrijven).

Demikian pula menurut hukum Islam, sangat jelas bahwa setiap hubungan seksual atau persetubuhan yang dilakukan di luar perkawinan yang sah adalah merupakan zina. Jika perbuatan pidana zina itu dapat dibuktikan sesuai dengan syariah Islam, maka hubungannya merupakan hak Allah, yaitu hudud. Hukuman rajam adalah bagi pelaku zina yang sedang dalam ikatan perkawinan, atau orang yang sudah pernah melakukan perkawinan yang sah kemudian bercerai, baik janda ataupun duda (muhshan atau muhshanah). Sedangkan hukuman jilid atau cambuk atau dera atau sebat dijatuhkan kepada pelaku zina yang belum pernah melakukan perkawinan, baik bujang maupun gadis. ${ }^{3}$

Jika perbuatan zina itu tidak dapat dibuktikan sesuai syariah Islam, maka hukumannya dapat di tentukan berdasarkan ta'zir. Menurut J. M. Van Bemmelen, di Belanda, delik zina sebagaimana dirumuskan dalam Pasal 284 KUHP (di Belanda di muat dalam Pasal $241 \mathrm{Sr}$ ) telah dihapus berdasarkan Undang-undang yang dikeluarkan pada tanggal 6 Mei 1971. Di Indonesia Pemidanaan bagi pelaku zina masih berdasarkan sebagaimana yang diatur dalam Kitab Undang Undang Hukum Pidana. Terdapat beragam pertimbangan Hakim dan bentuk pertanggung jawaban pidana bagi pelaku ziza yang dituangkan dalam putusan Pengadilan. Seperti pada putusan Nomor Putusan Pengadilan Negeri Bukit Tinggi, Tanggal 15 Oktober 2020, Nomor 90/PID.B /2020/PNBKT dimana telah terjadi perbuatan zina antara terdakwa Hilda Asel Pgl Hilda dengan Zulkifli (anggota TNI Aktif) keduanya masih terikat perkawinan yang sah. Terhadap keduanya masing dijatuhi pidana berupa pidana percobaan selama 9 (bulan) penjara.

\footnotetext{
${ }^{2}$ Ishak, Analisis Hukum Islam Tentang Perbuatan Zina Dalam Pasal 284 Kitab Undang-Undang Hukum Pidana Dalam Pembaharuan Hukum Pidana, Kanun, Jurnal Ilmu Hukum, No. 56, Volume XIV. 2012, Yogyakarta.

${ }^{3}$ Farihi, Hamid, Zina, Qadzaf dan Minuman Keras Dalam Perspektif Hukum Pidana Islam, Mizan: Jurnal Ilmu Syariah, No. 1, Volume II. 2014
} 
Permasalahan yang akan dibahas dalam penelitian ini adalah pertanggung jawaban pidana terhadap terdakwa pada tindak pidana perzinaan pada Putusan Nomor 70/PID.Sus/2020/PN-SWL dan Putusan Nomor 90/PID.B/2020/PN BKT

\section{METODE PENELITIAN}

Spesifikasi penelitian adalah deskriptif analitis, dengan metode pendekatan yuridis normative. Jenis data yang digunakan adalah data sekunder. Data sekunder diperoleh dari studi dokumen. Data yang diperoleh kemudian dianalisa secara kualitatif.

\section{PEMBAHASAN}

\section{A. Pertanggung Jawaban Pidana Terhadap Tindak Pidana Perzinaan Pada 70/PID.Sus/2020/PN-SWL Dan Putusan Nomor 90/Pid.B/2020/Pnbkt}

Pada Putusan Nomor 70/PID.Sus/2020/PN-SWL dimana terdakwa terbukti secara sah dan meyakinkan bersalah melakukan tindak pidana "dengan sengaja menjadi objek yang mengandung muatan pornografi dan seorang pria yang telah menikah, melakukan zina (overspel) padahal diketahui bahwa Pasal 27 BW berlaku baginya" sebagaimana dalam dakwaan kumulatif. Pidana terhadap Terdakwa adalah dengan pidana penjara selama 8 (delapan) bulan. Hakim tidak mempertimbangan perbuatan dengan sengaja menjadi objek yang mengandung muatan pornografi yang ditur pada undang undang pornografi namun hanya menjatuhkan pidana terhadap perbuatan perzinaan sebagaimana diatur dalam Pasal 284 ayat (1) ke 2 KUHP dengan pidana mendekati maksimal yaitu pidana penjara selama 9 bulan.

Pertanggungjawaban pidana tindak pidana perzinaan pada Putusan Nomor 90/PID.B/2020/PNBKT adalah "turut melakukan Perzinahan padahal diketahui masih terikat perkawinan yang sah". Dalam hal ini terdakwa adalah seorang yang masih belum terikat perkawinan sehingga dalam penjatuhan pidananya sesuai dengan tuntutan Jaksa Penuntut Umum, terdakwa adalah sebagai turut serta melakukan bukan pelaku utama atau "Dader". Terdakwa dianggap bersalah karena mengetahui bahwa saksi Zulkifli masih terikat perkawinan yang sah dengan saksi Ismarni namun tetap melakukan perbuatan zinah dengan terdakwa zulkifli yang diputuskan pidananya pada Pengadilan Militer. Berdasarkan pertimbangan hakim pada peradilan ini maka terdakwa dijatuhi pidana penjara selama 4 (empat) bulan. Hakim menetapkan pidana tersebut tidak perlu dijalani oleh Terdakwa, Kecuali Terdakwa dinyatakan bersalah karena melakukan tindak pidana lain berdasarkan putusan hakim yang sudah mempunyai kekuatan hukum tetap dalam masa percobaan selama 9 (sembilan) bulan. Terdakwa hanya diberi tanggung jawab untuk menjalani pidana bersyarat selam 9 (Sembilan) bulan.

Untuk sampai pada pengenaan pidana dalam delik perzinahan, harus diketahui terlebih dulu kedudukan perzinahan adalah merupakan salah satu dari delik aduan absolut. Dimana dalam delik aduan tidak dapat dilakukan penuntutan sebelum adanya pengaduan dari pihak yang merasa dirugikan oleh tindak pidana tersebut, yang secara tegas dinyatakan dalam Pasal 284 ayat 2 KUHP yaitu: "tidak dilakukan penuntutan melainkan atas pengaduan suami atau istri yang tercemar". Dari Pasal tersebut dapat ditarik kesimpulan bahwa tindak pidana perzinahan berkedudukan sebagai delik aduan, sehingga untuk menetapkan pidana terhadap perzinahan mutlak diperlukannya pengaduan dari 
pihak yang dirugikan.

Ancaman hukuman dalam Pasal 284 KUHP adalah maksimal Sembilan bulan penjara. Jika seseorang dihukum lima bulan, berarti hakim melihat ada unsur yang membuat pelaku tidak perlu dihukum maksimal. Dengan hukuman seberapa pun, jaksa atau terhukum berhak mengajukan banding. Tidak ada jaminan bahwa apabila terdakwa divonis bebas, jaksa tidak akan banding. Kalau sudah masuk proses hukum di pengadilan, tentu saja semua hak dapat dimanfaatkan oleh para pihak. Kelak, bila hakim banding menjatuhkan putusan maksimal, terdakwa berhak mengajukan kasasi.

Bukan berarti kasus zinah yang diatur Pasal 284 KUHP harus bergulir sepenuhnya ke meja hijau. Tindak pidana yang diatur pasal ini adalah delik aduan absolut. Artinya, pelaku tidak dapat dituntut apabila tidak ada pengaduan dari pihak suami atau isteri yang dirugikan. Meskipun demikian, pengaduan dimaksud tetap dapat dicabut asalkan selama perkara ini belum diperiksa dimuka pengadilan. Dengan kata lain, karena perkaranya sudah dilimpahkan jaksa ke pengadilan, maka pencabutan pengaduan oleh orang yang merasa dirugikan (suami atau isteri pelaku) tidak bisa mempengaruhi perkara. Mungkin saja, hakim menjadikan pencabutan aduan itu sebagai unsur yang meringankan.

Sifat lain yang perlu dicatat dari Pasal 284 KUHP adalah perkara tidak boleh dibelah. Maksudnya, apabila A (suami) mengadukan B (isteri) telah berzina dengan pria lain (C), maka A tidak boleh hanya mengadukan $\mathrm{C}$ dengan alasan masih sayang kepada isterinya. Pelaku perzinahan, dalam kasus ini B dan C, harus sama-sama diproses hukum. Bahwa kemudian jaksa tidak menuntut B ke muka persidangan, itu merupakan hak oportunitas jaksa untuk mengesampingkan perkara.

Apabila pada laki-laki atau perempuan yang melakukan zinah itu tidak berlaku Pasal 27 Burgerlijk Wetboek (selanjutnya disebut BW) sedangkan perempuan atau lakilaki yang menjadi kawannya melakukan zinah itu tunduk pada Pasal $27 \mathrm{BW}$, dan diketahuinya bahwa laki-laki atau perempuan yang berzinah itu tunduk pada BW, kualitasnya bukanlah melakukan kejahatan zinah, akan tetapi telah turut serta melakukan zinah, yang dibebani tanggung jawab yang sama dengan si pembuat zinah itu sendiri. Turut serta melakukan zinah ini, dilihat dari pasal 55 ayat (1) KUHP adalah sebagai pembuat peserta (mede pleger).

Pasal 27 BW adalah mengenai asas monogamy, dimana dalam waktu yang bersamaan seorang laki-laki hanya boleh dengan satu isteri, dan seorang perempuan hanya boleh dengan satu suami. Apa yang dimaksud dengan bersetubuh atau persetubuhan, Hoge Read dalam pertimbangan hukum suatu arrestnya (5-2-1912) menyatakan bahwa "persetubuhan adalah perpaduan antara alat kelamin laki-laki masuk kedalam alat kelamin perempuan yang kemudian mengeluarkan air mani"4. Sampai kini pengertian bersetubuh seperti itu tetap dipertahankan dalam praktik hukum. Apabila alat penis tidak sampai masuk kedalam vagina walaupun telah mengeluarkan air mani, atau masuk tetapi tidak sampai keluar sperma, menurut pengertian bersetubuh seperti itu, maka belumlah terjadi persetubuhan. Namun, telah terjadi percobaan persetubuhan, dan menurut ketentuan Pasal 53 telah dapat dipidana karena telah masuk percobaan berzinah.

Pengertian zinah menurut pasal 284 yang disyaratkan harus laki-laki atau

\footnotetext{
${ }^{4}$ R. Soesilo, Kitab Undang undang Hukum Pidana (KUHP) serta komentar komentarnya lengkap Pasal demi Pasal, Politea, Bogor, 1980, hlm. 181
} 
perempuan yang sedang kawin tersebut di atas, berlatar belakang pada pemikiran orangorang Belanda bahwa zina itu sebagai pengingkaran perkawinan, yang berbeda menurut hukum adat yang berlatar belakang pada penodaan nilai-nilai kesucian pada persetubuhan. Menurut hukum adat didalam persetubuhan itu terkandung nilai-nilai kesucian. Oleh karena itu, untuk melakukannya diperlukan syarat, yaitu perkawinan. Apabila dilakukan diluar perkawinan, dia berdosa dan telah melanggar nilai kesucian itu, dia telah berzinah, oleh sebab itu si pembuatnya harus dihukum.

Berdasarkan yang telah diterangkan mengenai zinah tersebut diatas, nyatalah pembentuk undang-undang telah mengadakan diskriminasi antara orang yang tunduk pada BW. Orang-orang Eropa dan orang Cina dengan orang-orang lainnya terutama penduduk asli Indonesia, yang pada umumnya orang-orang beragama islam yang tidak tunduk pada asas monogami. Oleh karena itu, penduduk asli Indonesia atau lainnya yang beragama islam, tidak dapat dipidana melakukan zinah, tetapi hanya dapat dipidana karena turut serta melakukan zinah dalam hal kawannya bersetubuh itu telah bersuami dan Pasal 27 BW berlaku baginya.

Dalam praktik pengadilan yang sekarang, SEMA tersebut di atas telah diturut oleh pengadilan-pengadilan di seluruh Indonesia. Kejahatan zinah merupakan tindak pidana aduan absolut, artinya dalam segala kejadian perzinahan itu diperlukan syarat pengaduan untuk dapatnya si pembuat atau pembuat pesertanya dilakukan penuntutan. Mengingat kejahatan zinah adalah tindak pidana yang untuk terwujudnya diperlukan dua orang, disebut dengan penyertaan mutlak, yang tidak dapat dipisahkan satu dengan yang lain (onsplitsbaarheid), walaupun si pengadu mengadukan satu orang saja di antara dua manusia yang telah berzinah itu, tidak menyebabkan untuk tidak dilakukannya penuntutan terhadap orang yang tidak diadukan oleh si pengadu. Akan tetapi, Jaksa Penuntut Umum, tidak menjadikan hapus haknya untuk tidak melakukan penuntut terhadap orang yang tidak diadukan berdasarkan asas opportunitas. Hal ini sesuai pula dengan pendapat Mahkamah Agung dalam pertimbangan hukum putusannya No. 52 K/Kr/1953 tanggal 19 Maret 1955, yang menyatakan bahwa "suatu pengaduan perihal kejahatan perzinahan (operspel), yang oleh suami hanya diajukan terhadap si lelaki yang tidak dapat dipisahkan (onsplitsbaarheid) dan pengaduan itu (pendapat Jaksa Agung). Pengaduan semacam itu berarti pengaduan juga terhadap istri yang melakukan perzinahan, tetapi Penuntut Umum leluasa untuk tidak menuntut si istri itu berdasarkan asas opportuniteit ${ }^{5}$.

Pengaduan yang dimaksud dapat diajukan dalam tenggang waktu tiga bulan, bagi yang tunduk pada BW diikuti dengan permintaan bercerai atau pisah meja dan tempat tidur. Akan tetapi, bagi yang tidak tunduk pada Pasal 27 BW syarat yang disebutkan terakhir tidak diperlukan. Dalm hal ini pengaduan semacam ini, Pasal 72, 73 dan 75 tidak berlaku. Pasal 72 mengenai pengadu yang belum dewasa yang umurnya belum genap enam belas tahun atau dibawah pengampuan. Pasal 73 tentang korban yang berhak mengadu meninggal dunia. Pasal 75 tentang hak menarik pengaduan dalam waktu tiga bulan. Pengaduan dapat ditarik sewaktu-waktu sebelum dimulainya pemeriksaan di siding pengadilan. Dalam praktik, pada siding pertama hakim terlebih dulu menanyakan pada saksi pengadu apakah dia tetap akan meneruskan pengaduannya, ataukah akan

\footnotetext{
${ }^{5}$ http://dhia-analisis-hukum-mengenai-tindak-pidanaperzinahan.html diakses pada tanggal 1 Mei 2021
} 
menariknya. Apabila dalam sidang itu si pengadu menyatakan dia menarik pengaduannya, maka hakim tidak melanjutkan dan menghentikan pemeriksaan. Apabila dalam sidang pertama itu pengadu tidak menariknya, untuk seterusnya dia tidak dapat lagi menarik pengaduan itu.

\section{B. Pertimbangan Hakim Terhadap Tindak Pidana Perzinaan Pada Putusan Nomor 70/PID.Sus/2020/PN-SWL Dan Putusan Nomor 90/Pid.B/2020/PnBKT}

Keadilan merupakan hal yang abstrak, namun dapat dilihat secara konkrit pada setiap pencari keadilan. Sehingga hakim dalam putusannya pada perkara pidana, seharusnya putusan hakim tersebut berisi alasan-alasan dan pertimbangan-pertimbangan yang rasional, sehingga bagi pencari keadilan dapat menemukan nilai keadilan pada putusan hakim. Pertimbangan-pertimbangan hakim tersebut sebagai motivasi yang jelas dari tujuan putusan diambil, yaitu untuk menegakkan hukum (kepastian hukum) dan memberikan keadilan. ${ }^{6}$

Selanjutnya dalam penelitian ini adalah mengenai pertimbangan hakim pada pengenaan pasal 284 ayat (1) ke-1a KUHP dengan unsur-unsur yang dianggap terpenuhi. Adapun pertimbangan hakim pada Putusan Nomor 70/PID.Sus/2020/PN-SWL terpenuhinya unsur perzinaan dan unsur merekam perbuatan zina yang dilakukan. Pertimbangan yuridis adalah pertimbangan terhadap terpenuhinya unsur unsur yang terdapat dalam pasal yang didakwakan oleh penuntut umum.

Pertimbangan terhadap setiap unsur yang terdapat dalam Pasal 284 ayat (1) ke1a KUHP adalah pertama tentang subyek hukumnya yaitu orang. Orang sebagai subyek hukum yang mampu bertanggungjawab atas perbuatannya. setiap orang dalam Perkara ini adalah terdakwa yang identitasnya telah disebutkan dalam surat dakwaan dan telah pula dibenarkan oleh Terdakwa. Terdakwa selama menghadiri persidangan ini dapat memahami dengan terang segala sesuatu yang berhubungan dengan dakwaan yang diajukan kepadanya, dan dapat memberikan keterangan tentang apa-apa yang telah diperbuatnya, sehingga tidak ditemukan hal-hal yang menerangkan bahwa Terdakwa tidak mampu untuk bertanggung jawab terhadap perbuatannya, dengan demikian Majelis Hakim berpendapat unsur "barang siapa" telah terpenuhi.

Pertimbangan yuridis terhadap unsur "Dengan sengaja atau atas persetujuan dirinya menjadi objek atau model yang mengandung muatan pornografi. Kesengajaan diuraikan dalam M.v.T. (Memorie van Toelichting), yaitu; "Pidana pada umumnya hendaknya dijatuhkan hanya pada barang siapa melakukan perbuatan yang dilarang, dengan dikehendaki dan diketahui". Dalam pengertian ini disebutkan bahwa kesengajaan diartikan sebagai "menghendaki dan mengetahui" (willens en wetens), artinya seseorang yang melakukan suatu tindakan dengan sengaja, harus menghendaki serta menginsafi tindakan tersebut dan atau akibatnya. Jadi dapatlah dikatakan, bahwa sengaja berarti menghendaki dan mengetahui apa yang dilakukan. Orang yang melakukan perbuatan dengan sengaja menghendaki perbuatan itu dan mengetahui atau menyadari pula tentang apa yang dilakukan itu serta akibat yang akan ditimbulkannya. Berdasarkan Pasal 1

${ }^{6}$ Djanggih, H., \& Ahmad, K. (2017). The Effectiveness of Indonesian National Police Function on Banggai Regency Police Investigation (Investigation Case Study Year 2008-2016). Jurnal Dinamika Hukum, 17(2), 152-157 
Angka 1 Undang-Undang Republik Indonesia Nomor 44 Tahun 2008 Tentang Pornografi disebutkan bahwa Pornografi adalah gambar, sketsa, ilustrasi, foto, tulisan, suara, bunyi, gambar bergerak, animasi, kartun, percakapan, gerak tubuh, atau bentuk pesan lainnya melalui berbagai bentuk media komunikasi dan/atau pertunjukan di muka umum, yang memuat kecabulan atau eksploitasi seksual yang melanggar norma kesusilaan dalam masyarakat. Jenis-jenis perbuatan dengan sengaja yang terkandung didalam unsur ini meliputi menjadi objek atau model yang mengandung muatan pornografi (Pornografi adalah gambar, sketsa, ilustrasi, foto, tulisan, suara, bunyi, gambar bergerak, animasi, kartun, percakapan, gerak tubuh, atau bentuk pesan lainnya melalui berbagai bentuk media komunikasi dan/atau pertunjukan di muka umum, yang memuat kecabulan atau eksploitasi seksual yang melanggar norma kesusilaan dalam masyarakat), yang mengandung elemen yang bersifat alternatif yaitu apabila salah satu atau lebih elemen dari unsur ini telah terbukti, maka sudah cukup unsur ini dinyatakan telah terbukti.

Hal tersebut sesuai dengan perbuatan terdakwa telah melakukan hubungan intim bersama seorang perempuan yang bernama Karyanah (DPO) dan merekam perbuatannya itu ke dalam bentuk beberapa potongan video dan foto. Perbuatan-perbuatan Terdakwa dengan seseorang perempuan tersebut melakukan hubungan intim layaknya suami istri dan merekam perbuatan mereka tersebut ke dalam bentuk beberapa video (gambar bergerak) dan beberapa foto vulgar. Video tersebut tidak pernah disebar luaskan.

Unsur seorang pria yang telah menikah dapat dibuktikan dengan pengertian seseorang yang telah nikah dalam unsur ini adalah seseorang laki-laki yang tunduk dalam ketentuan Pasal 27 BW, dan berdasarkan ketentuan Surat Edaran Mahkamah Agung Nomor 8 Tahun 1980 Tentang Pasal 284 Ayat (1) Ke-1 Huruf a Kitab Undang-Undang Hukum Pidana, maka ketentuan dalam Undang-Undang Nomor 1 Tahun 1974 tentang Perkawinan dapat pula diberlakukan terhadap Pasal 284 ayat (1) ke-1 huruf a Kitab Undang-Undang Hukum Pidana. Unsur perzinaan jelas terbukti dari rekaman video persetubuhan yang diambil mereka.

Pada Putusan Nomor 90/PID.B/2020/PNBKT perzinaan dilakukan oleh terdakwa seorang perempuan dengan saksi Zulkifli (anggota TNI Aktif). Dimana laki laki tersebut telah diadili di Pengadilan Militer I-03 Padang. Berdasarkan putusan Peradilan Militer I03 Padang Nomor: 01-K/PM. I-03/AD/I/2020 tanggal 06 Februari 2020 telah terbukti secara sah dan meyakinkan bersalah melakukan Tindak Pidana Perzinahan padahal diketahuinya saksi Zulkifli masih terikat perkawinan yang sah terbukti dengan Kutipan Akta Nikah Nomor : 237/29/X/1998 tanggal 20 Oktober 1998 yang dikeluarkan oleh Kantor Urusan Agama Kec. Suliki GN. Mas Kabupaten 50 Kota Sumatera Barat.

Perbuatan perzinaan diketahui oleh saksi Deni Ricardo mendapatkan informasi bahwa saksi Zulkifli sedang berada di rumah Terdakwa, kemudian saksi Deni Ricardo bersama unit Intel Kodim 0304 Agam datang ke rumah Terdakwa untuk mencari saksi Zulkifli, saat itu Terdakwa mengatakan bahwa saksi Zulkifli tidak ada dirumahnya, kemudian saksi Deni Ricardo meminta izin Terdakwa untuk mencarinya di dalam rumah dan saksi Zulkifli ditemukan bersembunyi di dalam kamar mandi bagian belakang rumah Terdakwa yang saat itu sedang menggunakan celana pendek. Kemudian Terdakwa dan saksi Zulkifli dibawa ke kantor Kodim 0304 Agam untuk dimintai keterangan. 


\section{KESIMPULAN}

1. Bentuk pertanggung jawaban pidana terhadap perbuatan zina dapat lebih diperberat lagi dari ancaman 9 bulan penjara yang dianggap terlalu ringan. Hal ini dengan pertimbangan bahwa perbuatan zina adalah perbuatan yang sangat tercela dari sisi Agama dan kesopanan dalam masyarakat.

2. Hakim dalam pertimbangannya dapat memasukan unsur unsur yang memberatkan terdakwa seperti adanya bentuk tindak pidana lain yang bersifat khusus yang dilakukan selain daripada zina seperti tindak pidana pornografi.

\section{DAFTAR PUSTAKA}

Hanif Nurcholis, Teori dan Praktik Pemerintahan \& Otonomi Daerah, Grasindo, Jakarta, 2007

Hamid Farihi, Zina, Qadzaf dan Minuman Keras Dalam Perspektif Hukum Pidana Islam, Mizan: Jurnal Ilmu Syariah , No. 1, Volume II. 2014

Ishak, Analisis Hukum Islam Tentang Perbuatan Zina Dalam Pasal 284 Kitab UndangUndang Hukum Pidana Dalam Pembaharuan Hukum Pidana, Kanun, Jurnal Ilmu Hukum, No. 56, Volume XIV. 2012, Yogyakarta.

Djanggih, H., \& Ahmad, K. (2017). The Effectiveness of Indonesian National Police Function on Banggai Regency Police Investigation (Investigation Case Study Year 2008-2016). Jurnal Dinamika Hukum, 17(2),

R. Soesilo, Kitab Undang undang Hukum Pidana (KUHP) serta komentar komentarnya lengkap Pasal demi Pasal, Politea, Bogor, 1980, hlm. 181 